Egyptian J. of Nutrition Vol. XXXIV No. 1 (2019)

\title{
Effect of Fortified Diet with Avocado Fruits and Zinc Chloride of Rats Suffering from Diabetes and Osteoporosis
}

\author{
Dalia Mohamed Talatt Abd EL-khalik \\ Home Economic Dept., Faculty of Specific Education, Fayoum \\ University.
}

\begin{abstract}
This study aimed to investigate the effect of fortified diet with avocado fruits and zinc chloride of rats suffering from diabetes and osteoporosis. Forty eight female Sprague-Dawley rats were divided into two main groups as follows: The first main group 6 rats fed on basal diet, as a control negative group. The second main group (42 rats) injected with alloxan monohydrate $90 \mathrm{mg} / \mathrm{kg}$ body weight to induced hyperglycemia. After 7 days serum glucose was determined in the first and second main groups to insure the induction. Rats in the second main group (diabetic rats) received oral prednisone acetate $(4.5 \mathrm{ml} / \mathrm{kg}$ body weight/day twice a week) for two weeks to induce osteoporosis. After this period, the rats in the second main group were divided into seven subgroups ( $n=6$ rats) as follows: Subgroup (1): fed on basal diet (control positive group). Subgroup (2 and 3): were fed on basal diet containing $7.5 \%$ and $15 \%$ avocado fruits, respectively. Subgroup (4 and 5): were fed on basal diet containing $2 \mathrm{~g}$ and $4 \mathrm{~g}$ zinc chloride in the mineral mixture, respectively. Subgroup (6 and 7): were fed on basal diet containing ( $7.5 \%$ avocado fruits and $2 \mathrm{~g}$ zinc chloride in the mineral mixture) and (15\% avocado fruits and $4 \mathrm{~g}$ zinc chloride in the mineral




\section{Dalia Mohamed Talatt Abd EL-khalik}

mixture),respectively. During the experimental period, the diets consumed and body weights were recorded twice weekly. The results showed that, the highest improvement in lipid profile recorded for the groups which were treated with diet containing (15\% avocado and $4 \mathrm{~g}$ zinc chloride in the mineral mixture), $7.5 \%$ avocado and $2 \mathrm{~g}$ zinc chloride in the mineral mixture and $15 \%$ avocado, respectively. The highest levels of avocado fruits and zinc chloride together (15\% avocado and $4 \mathrm{~g}$ zinc chloride) recorded the best results in bone status. Serum glucose improved in groups which were treated with (15\% avocado and $4 \mathrm{~g}$ zinc chloride together), followed by the groups treated with (7.5\% avocado and $2 \mathrm{~g}$ zinc chloride together), and $4 \mathrm{~g}$ zinc chloride, respectively. Serum and liver zinc increased gradually with increasing the levels of avocado and zinc chloride in the diets. From these results, it could be concluded that, the fortified diet with avocado fruits and zinc chloride improved the nutritional and biochemical parameters of diabetic rats suffering from osteoporosis.

\section{Introduction}

Diabetes has become a serious and increasing health problem in worldwide. About three hundred and eighty-two million people in the world suffering from diabetes in 2013, this number will arrive to five hundred and ninety-two in 2035 (Guariguata et al., 2014). Diabetic patients often suffer from osteoporosis (Schwartz, 2003).

Osteoarthritis is a disease that affects women in general after menopause; also, osteoporosis is a major problem in older men. Statistics show that $30 \%$ of hip fractures occur for men. Statistics show also 1 in 8 men older than 50 years will have an osteoporotic fracture (Campion and Maricic, 2003). 
Egyptian J. of Nutrition Vol. XXXIV No. 1 (2019)

Zinc is an essential mineral for human health. It is essential for the formation of collagen and deposition of minerals in the bones (Calhoun et al., 1974). On the other hand, zinc deficiency led to abnormalities in bone growth, bone formation, and mineralization in animals (Yamaguchi, 1998). In addition, deficiency of zinc associated with low bone mass in women (Angus et al., 1988). Urinary zinc excretion increased in women with osteoporosis, this phenomenon leads to decrease serum or plasma zinc concentration (Gur et al., 2002).

Rodríguez-Monforte et al., (2015) reported that, diet based on plant sources is associated with lower risk of cardiovascular disease CVDs. On the other hand, fruit play an important role in preventing CVDs. McCormack et al., (2010) and Fulgoni et al., (2013) reported that, avocado consumption is associated with reduced the risk of metabolic syndrome, because avocados contain a variety of vitamins, minerals and phytochemicals such as lutein, phenolic antioxidants, and phytosterols associated with numerous potential health benefits. The researchers reported that nutritionists should be aware of the beneficial associations between avocado intake, diet and health when making dietary recommendations.

Such minerals and vitamins play an important role in maintenance of healthy bone (Ilich and Kerstetter, 2000). Both zinc intake and blood zinc each have a positive association with bone mineral density BMD in men (Hyun et al., 2004). Zinc supplements in postmenopausal women may result a beneficial reduction in osteoporotic risk (Razmandeh et al., 2014).

The aim of the present study is to determine if supplemented diet with avocado fruits, zinc chloride and their combination alter the 


\section{Dalia Mohamed Talatt Abd EL-khalik}

weight gain, lipid profile, bone status, glucose and zinc in serum and liver of rats suffering from osteoporosis.

\section{Materials and Methods}

\section{Materials:}

- Casein, vitamins, minerals, cellulose, choline chloride and alloxan obtained from El-Gomhoria Company, Cairo, Egypt.

- Fresh Avocado fruits (Persea Americana) was purchased from Field Crops Research Institute, Ministry of Agriculture Giza, Egypt.

- Glucocorticoid (prednisone acetate) will be obtained from the pharmacy, Cairo, Egypt.

- Starch and soy oil were obtained from local market.

- Normal 48 female albino rats Spraque - Dawely Strain (150 $\pm 5 \mathrm{~g}$ )

Purchased from Helwan Experimental Animals station.

\section{Methods:}

\section{Preparation of avocado fruits.}

Avocado fruits were washed by using tap water to remove dust, and then peeled off and the creamy pulps were homogenized using electric blender, according to the method described by (Alghamdi and Yousef, 2017).

\section{Chemical analysis of Avocado.}

Moisture, fiber, ash, protein and fat content were determined according to the method outlined in A.O.A.C. (2000). Total carbohydrates were determined by difference.

\section{Biological Part:}

Forty-eight Sprague - Dawley strain female albino rats, weighting $(150 \pm 5 \mathrm{~g})$ used in this study. All rats fed on basal diet for 7 consecutive days to adaptation. Each rat was housed in an 


\section{Egyptian J. of Nutrition Vol. XXXIV No. 1 (2019)}

individual stainless steel cage under hygienic controlled condition. The basal diet consists of casein (14\%), corn oil (4\%), choline chloride $(0.25 \%)$, and vitamin mixture $(1 \%)$, cellulose $(5 \%)$ and the remainder is corn starch according to Reeves et al., (1993), salt mixture which used in these study prepared according to Hegsted et al., (1941) and vitamin mixture prepared according to A.O.A.C. (1975).

After adaptation period, the rats divided into two main groups as follows: The first main group ( 6 rats) fed on basal diet, as a control negative group. The second main group (42 rats) injected intraperitoneally (i.p.) with alloxan monohydrate $90 \mathrm{mg} / \mathrm{kg}$ body weight to induced hyperglycemia, according to (Ibegbulem and Chikezie, 2013). After 7 day serum glucose was determined in the first and second main groups to insure from the induction (65.786 \pm $4.323 \mathrm{mg} / \mathrm{dl})$ in the first main group vs. $(121.321 \pm 3.543 \mathrm{mg} / \mathrm{dl})$ in the second main group. Rats in the second main group (diabetic rats) received oral prednisone acetate $(4.5 \mathrm{ml} / \mathrm{kg}$ body weight/day twice a week) and fed on basal diet for two weeks to establish osteoporotic models according to Liao et al., (2003). After this period, the rats in the second main group were divided into seven subgroups ( $n=6$ rats) as follows: Subgroup 1: fed on basal diet (control positive group). Subgroup 2 and 3: were fed on basal diet containing $7.5 \%$ and $15 \%$ avocado fruits, respectively. Subgroup 4 and 5: were fed on basal diet containing $2 \mathrm{~g}$ and $4 \mathrm{~g}$ zinc chloride in the mineral mixture, respectively. Subgroup 6 and 7: were fed on basal diet containing ( $7.5 \%$ avocado fruits and $2 \mathrm{~g}$ zinc chloride in the mineral mixture) and (15\% avocado fruits and $4 \mathrm{~g}$ zinc chloride in the mineral mixture), respectively. 


\section{Dalia Mohamed Talatt Abd EL-khalik}

During the experimental period (28 days), the diets consumed and body weights were recorded twice weekly according to Chapman et al., (1959). Blood samples were collected from the aorta at the end of the experiment period, after fasted overnight and anaesthetized. The blood samples were centrifuged and the serum was separated to estimate the following biochemical parameters, i.e. serum cholesterol according to (Allain et al., 1974), triglycerides (Foster and Dumns, 1973), high density lipoprotein (HDL-C) (LopesVirella et al., 1977), low density lipoprotein (LDL-C) and very low density lipoprotein (VLDL-C) (FriedWald et al., 1972), serum calcium (Baginski, 1973), serum phosphorus (Yee, 1968). Femur bones (Right and left) were removed from each rats, cleaned. Femur bones were put in a foil paper and kept in deep -freezer. Bone Mineral Density (BMD) and Bone Mineral Concentration (BMC) measured by Dual Energy X-ray Absorptiometry (DEXA) in National Research Center, Osteoporosis Unit. Calcium and phosphorus in femur bone of rats were determined according to the method described by Muynck and Vanhaecke, (2009). Serum glucose (Trinder, 1959) and zinc in serum and liver according to Jayalakshmi and Platel, (2016).

The obtained data was analyzed statistically for mean \pm standard deviation and one-way ANOVA test (Sendecor and Cochran, 1979).

\section{Results and Discussion}

\section{Chemical composition of avocado fruits.}

The data in Table (1) revealed that, the amounts of moisture, protein, fat, ash, carbohydrates and fiber in avocado fruits were $65.18,2.05,15.51,1.20,9.00$ and $7.06 \mathrm{~g} / 100 \mathrm{~g}$, respectively. These 
Egyptian J. of Nutrition Vol. XXXIV No. 1 (2019)

results agree with (Alghamdi and Yousef, 2017) who reported that, the (moisture, protein, ash, carbohydrate, fiber and fat) contents in edible portion of avocado were $63 ; 2.12 ; 1.03 ; 9.87 ; 7.25$ and 16.02 ( $\mathrm{g} / 100 \mathrm{~g}$ edible portion), respectively.

\section{Effect of fortified diet with avocado fruits and zinc chloride on feed intake and weight changes of rats suffering from diabetes and osteoporosis.}

The effect fortified diets with two levels of avocado, zinc chloride and their combination on feed intake (g/day), weight ( $\mathrm{g}$ ) and body weight gain \% of diabetic rats suffering from osteoporosis presented in Table (2). The mean value \pm SD of feed intake ( $/$ /day/ each rat) of the control positive group fed on basal diet decreased significantly $(p \leq 0.05)$, as compared to the negative control group $(15.034 \pm 0.212$ vs. $16.910 \pm 0.618 \mathrm{~g})$, respectively. All treated groups showed significant increase $(p \leq 0.05)$ in the mean value of feed intake, as compared to the positive control group, except the group, which was treated with $15 \%$ avocado fruits and the group treated with the combination of high levels from avocado and zinc chloride. In this respect, Wien et al., (2013) reported that, adding half avocado (70 g) in the lunch of overweight and moderately obese individuals increased the satiety from 3 to 5 subsequent hours, followed by a reduction of the insulin secretion.

Data presented in the same Table showed that, nonsignificant changes in the initial weight of healthy rats and other treated rats. On the other hand, final weight of the positive control group decreased significantly ( $p \leq 0.05$ ), as compared to the negative control group. Zafar and Naqvithat, (2010) found that, the STZinduced diabetes induced significant decrease in the body weight of diabetic animals. On the other hand, Jane et al., (2000) found that, 


\section{Dalia Mohamed Talatt Abd EL-khalik}

administration of glucocorticoids at a dosage of $5 \mathrm{mg} / \mathrm{kg} /$ day for 5 days would result in a decrease in both body and diaphragm weights.

The mean value of final weight of the positive control group decreased by about $12.269 \%$, than that of the negative control group. Final weights of all treated groups showed non-significant change, as compared to the positive control group.

The mean value of body weight gain \% (BWG\%) of the positive control group (diabetic rats which suffer from osteoporosis) decreased significantly ( $p \leq 0.05)$, as compared to the negative control group (healthy rats). All tested diet caused non-significant differences in BWG\% ( $\leq \leq 0.05)$, except group of rats which treated with diet containing $7.5 \%$ avocado and $2 \mathrm{~g}$ zinc chloride, as compared to the positive control group. In this respect, Chen et al., (2000) reported that zinc treatment did not affect body weight gain, body fat content or food intake in these diabetic mice. On the other hand, USDA, (2011) and Bes-Rastrollo et al., (2008) reported that, avocados are a medium energy dense fruit because avocado edible fruit consists of $72 \%$ water and $6.8 \%$ dietary fiber and has been shown to have similar effects on weight control as low-fat fruits and vegetables.

Effect of fortified diet with avocado fruits and zinc chloride on lipid profile of rats suffering from diabetes and osteoporosis.

Table (3) showed the effect of diets containing two levels of avocado, zinc chloride and their combinations on lipid profile including, serum cholesterol, triglyceride, high density lipoproteincholesterol (HDL-c), low density lipoprotein-cholesterol (LDL-C) and very low density lipoprotein-cholesterol (VLDL-c). 
Egyptian J. of Nutrition Vol. XXXIV No. 1 (2019)

The mean values of serum cholesterol, triglyceride, LDL-c and VLDL-c in the positive control group increased significantly $(p \leq 0.05)$, while HDL-c decreased, as compared to the negative control group. HDL-c lower in positive control group than that of the negative. Sultania et al., (2017) reported that, diabetes is a chronic disease, characterized by disorders of the metabolism of carbohydrates, fat and protein, resulting in a deficiency in the secretion of insulin, or the action of insulin or both. In addition, the dyslipidemia commonly occur in diabetes, included elevation of the levels of LDL-C and triglyceride, and lowering the levels of high-density lipoprotein cholesterol (HDLC). On the other hand, prednisolone is a synthetic glucocorticoid that has been used over the last few decades' treatment of several diseases (Rhen and Cidlowski, 2005). The level of LDL-c increased significantly in patients receiving prednisolone as compared to the patients received hydrocortisone (Quinkler et al., 2017).

All tested groups improved the lipid profile, except triglyceride and VLDL-c in the group, which treated with diet containing $2 \mathrm{~g}$ zinc chloride. Lipid profile improved gradually with increasing the levels of avocado, zinc chloride and (avocado and zinc chloride together). The highest improvement in lipid profile recorded for the groups which were treated with diet containing (15\% avocado and $4 \mathrm{~g}$ zinc chloride in the mineral mixture), $(7.5 \%$ avocado and $2 \mathrm{~g}$ zinc chloride in the mineral mixture) and $15 \%$ avocado, respectively.

In this respect, Riboli and Norat, (2003) reported that, fruits and vegetables decreased the risk of heart diseases. Avocado consumption improved the lipid profile including decreases serum total cholesterol, LDL-cholesterol and triglycerides and increases HDL-cholesterol levels, as compared to control diet subjects (LopezLedesma et al., 1996). 


\section{Dalia Mohamed Talatt Abd EL-khalik}

Healthy fats, such as mono and polyunsaturated fatty acids (MUFA) and (PUFA), has been associated with lower cardiovascular disease (CVD) risk in epidemiological studies (Schwingshack et al., 2011). On the other hand, Wang et al., (2010) and Dreher and Davenport, (2013) reported that avocado fruits are rich source in monounsaturated fatty acids (MUFAs), the average Hass avocado provides $136 \mathrm{~g}$ of edible fruit whose oil consists of $71 \%$ MUFAs, $13 \%$ PUFAs, and $16 \%$ SFAs. In addition to the fruit constituents of fiber, vitamins $B$, vitamins $K 1$, vitamin $E$, magnesium and potassium, phytochemicals such as carotenoids, phenolics, and phytosterols, which play an important role in improving the lipid profile.

On the other side, Ranasinghe et al., (2015) reported that, supplementation of zinc reduced total cholesterol, low density lipoprotein- cholesterol and triglycerides significantly, and they reported also, zinc reduced the incidence of atherosclerosis related morbidity and mortality. In addition, different human studies have showed that zinc supplementation decreased the mean value of total cholesterol, low density lipoprotein-cholesterol and triglycerides, while increasing the mean value of high density lipoprotein-cholesterol (Hashemipour et al., 2009) and (Kadhim et al., 2006). Zincenriched diet has beneficial effects in cholesterol and triglycerides on basal and postprandial glycaemia (Ghayour-Mobarhan et al., 2005).

\section{Effect of fortified diet with avocado and zinc chloride on bone status of rats suffering from diabetes and osteoporosis.}

Diabetic rats which were suffering from osteoporosis (control positive group), showed significant decrease $(p \leq 0.05)$ in femur bone (calcium "Ca" and phosphorus "P"), serum $\mathrm{Ca}$ and $\mathrm{P}$, bone mineral density (BMD) and bone mineral concentration (BMC), as compared to healthy rats (control negative group). In this respect, (Leidig- 


\section{Egyptian J. of Nutrition Vol. XXXIV No. 1 (2019)}

Bruckner and Ziegler, 2001) reported that, osteoporosis is one of the most important diseases for people with diabetes.

On the other hand, Gudbjornsson et al.,(2002) reported that, glucocorticoid-induced osteoporosis (GIO) is one of the serious side effects, which have become the most common secondary osteoporosis in adults. Nishimoto et al (1985) reported that, imbalance between bone resorption and bone formation led to osteoporosis.

Treating diabetic rats, which were suffering from osteoporosis with diet containing ( $7.5 \%$ and $15 \%$ avocado fruits), $2 \mathrm{~g}$ and $4 \mathrm{~g}$ zinc chloride and their combinations, led to significant increase $(p \leq 0.05)$ in all parameters calcium "Ca" and phosphorus "P" in the serum and bone, BMD and BMC, as compared to the positive control group (Table 4). The mean value of femur bone ( $\mathrm{Ca}$ and $\mathrm{P}$ ), serum ( $\mathrm{Ca}$ and $P), B M D$ and BMC increased gradually with increasing the levels of avocado fruits and zinc chloride. The highest concentration of these parameters recorded for the group which treated with diet containing ( $15 \%$ avocado and $4 \mathrm{~g}$ zinc chloride together), followed by the group treated with diet containing (7.5\% avocado and $2 \mathrm{~g}$ zinc chloride) and $15 \%$ avocado, respectively.

The highest levels of avocado fruits and zinc chloride together ( $15 \%$ avocado and $4 \mathrm{~g}$ zinc chloride) recorded the best results in bone status. This treatment increased the mean values of femur bone $\mathrm{Ca}$, femur bone "P", serum Ca, serum "P", BMD and BMC by about $42.172 \%, 78.183 \%, 40.397 \%, 37.532 \%, \quad 143.859 \%$ and $189.743 \%$ respectively, than that of the positive control group. 


\section{Dalia Mohamed Talatt Abd EL-khalik}

In this respect, Wang et al., (2010) and Dreher and Davenport ,2013) reported that avocado fruits are rich source in monounsaturated fatty acids (MUFAs), the average Hass avocado provides $136 \mathrm{~g}$ of edible fruit whose oil consists of $71 \%$ MUFAs, $13 \%$ PUFAs, and $16 \%$ SFAs. Coetzee et al., (2007) reported that, omega3 fatty acids (FAs) could prevent age-related bone loss by inhibiting osteoclastogenesis while improving osteoblast differentiation. Moreover, omega-3 FAs enhance calcium absorption by modifying the lipid composition of the intestinal cell membrane and decreasing intestinal calcium loss (Kruger and schollum, 2005). On the other hand, the avocado fruits consists of fiber, vitamins $B$, vitamins $K 1$, vitamin $E$, magnesium and potassium, phytochemicals such as carotenoids, phenolics, and phytosterols (Wang et al., 2012) and (Dreher and Davenport, 2013). Vitamin E supplements suppress serum gamma-tocopherol levels and may have negative effects on bone formation (Hamidi et al., 2012). Most of the experimental and clinical data available in the literature point to magnesium $\mathrm{Mg}$ as a contributor factor to bone health. Consequently, optimizing Mg intake might represent an effective and low-cost preventive measure against osteoporosis in individuals with documented $\mathrm{Mg}$ deficiency (Leidi et al., 2011). Dietary intake of $\beta$-carotene and $\beta$-cryptoxanthin may have a positive effect on bone health (Regu et al., 2017). Laboratory studies suggest that avocado and soy unsaponifiables (ASU) may facilitate repair of Osteoarthritis $(O A)$ cartilage through its effect on osteoblasts (Dinubile, 2010).

Hill et al., (2005) showed that a relationship between zinc nutritive status and bone turnover in elder adults. In addition to, Zhang et al., (2003) and Hambidge, (2003) reported that, rats need zinc to complete the physiological role of vitamin $D$ in calcium metabolism, and they suggests that zinc may play an important role 
Egyptian J. of Nutrition Vol. XXXIV No. 1 (2019)

in bone health. Relea et al., (1995) and Herzberg et al., (1990) reported that, zinc secretion is increased in the urine in osteoporotic women. On the other side, Spencer et al., (2013) shown that high zinc consumption decreased the absorption of calcium in the intestine during a low calcium intake, while did not occur during a normal calcium intake.

Effect of fortified diet with avocado and zinc chloride on serum glucose, zinc in serum and liver of rats suffering from diabetes and osteoporosis.

Injected rats with alloxan and treated with prednisone acetate (positive control group) increased the mean value of serum glucose and decreased the mean values of zinc in serum and liver significantly ( $\leq 0.05$ ), as compared to healthy rats (control negative group), $(146.800 \pm 2.387 \mathrm{mg} / \mathrm{dll}, 136.720 \pm 2.942 \mu \mathrm{g} / \mathrm{dl}$ and $21.890 \pm$ $0.880 \mu \mathrm{g} / \mathrm{g})$ vs. $(81.400 \pm 3.361 \mathrm{mg} / \mathrm{dl}, 179.280 \pm 4.432 \mu \mathrm{g} / \mathrm{dl}$ and $33.196 \pm 1.511 \mu \mathrm{g} / \mathrm{g}$ ), respectively. In this respect, Stanely et al., (2004) reported that, alloxan induces diabetes by damaging the insulin secreting cells of the pancreas leading to hyperglycemia. In addition to, Kahn et al., (1978) reported that, administration of glucocorticoids in vivo may also impair insulin binding to target cells, and this could provide another cause for glucocorticoid-induced insulin resistance.

On the other side, Daradkeh et al., (2014) reported that, zinc deficiency is common among type 2 diabetic patients due to hyperglycemia and polyuria. In addition, the low zinc status in conjunction with abnormal BMD may be strongly associated with osteoporosis in the studied patients (Al-Timimi et al., 2017). 


\section{Dalia Mohamed Talatt Abd EL-khalik}

The mean value of serum glucose increased in the positive control group by about $80.343 \%$, than that of the negative control group. All treated diabetic groups that suffer from osteoporosis with two levels from avocado, zinc chloride and their combinations showed significant decrease ( $p \leq 0.05)$ in serum glucose, as compared to the positive control group. On the other hand, serum glucose decreased gradually with increasing the levels of avocado and zinc chloride.

The highest decrease in the mean value of serum glucose recorded for the group treated with diet containing (15\% avocado and $4 \mathrm{~g}$ zinc chloride together), followed by the groups treated with $(7.5 \%$ avocado and $2 \mathrm{~g}$ zinc chloride together), and $4 \mathrm{~g}$ zinc chloride, respectively.

In this respect, Oboh et al., (2014) reported that, extracts of phenolic compounds from avocado leaves or fruits led to inhibit the activity of enzymes related to the development of Type 2 Diabetes ( $\alpha$ amilase and $\alpha$-glucosidase), as well as the malondialdehyde production (MDA), a marker of oxidative stress and responsible for increasing the lipid peroxidation. Also, Rao and Adinew, (2011) reported that, the hypoglycemic effect of the avocado fruits nay be due to its ability to stimulate the remaining pancreatic $\beta$-cells in animal models, making them able to secrete more insulin. Mono unsaturated fatty acids are considered alternatives for the dietary treatment of Type 2 Diabetes (Ros, 2003), avocado have a substantial amount of Mono unsaturated fatty acids it could be used as an option for glycemic control in diabetic patients. While Wien et al., (2013) reported that, adding half avocado $(70 \mathrm{~g})$ in the lunch of overweight and moderately obese individuals increased the satiety 
Egyptian J. of Nutrition Vol. XXXIV No. 1 (2019)

from 3 to 5 subsequent hours, followed by a reduction of the insulin secretion.

Khan and Safdar, (2003) reported that, zinc is an important mineral. Zinc has an active role in the metabolism of glucose and fat, and has a vital role in hormone function and also wound healing. Zinc is necessary for health and growth, and it is necessary for the function and activities of enzymes. On the other hand, Toma et al., (2014) decided that that, zinc plays an important role in the synthesis, storage and secretion of insulin. It also has an effective role in managing blood glucose and reducing its complications. Supplementation of zinc in rats before treatment with alloxan or dithiozone prevented hyperglycemia and destruction of islets (Jansen et al, 2009).

Zhang et al.,(2012) reported that reduced hepatic zinc concentration were found in diabetics mice Zinc deficiency has contributed to increase serum concentrations of ALT and deposit of lipids in the liver of the mice.

The mean value of zinc in (serum and liver) decreased in the positive group by about $23.739 \%$ and $34.058 \%$ respectively, than that of the negative group. Treating groups, which suffer from diabetes and osteoporosis with diets containing two levels from avocado, zinc chloride and their combination, led to significant increase $(p \leq 0.05)$ in the mean value of serum and liver zinc, as compared to the positive control group. Serum and liver zinc increased gradually with increasing the levels of avocado and zinc chloride in the diets.

Treated diabetic rats, which suffer from osteoporosis with the two levels from zinc chloride, increased the mean values of serum 


\section{Dalia Mohamed Talatt Abd EL-khalik}

and liver zinc significantly $(p \leq 0.05)$, as compared to the rats treated with the two levels from avocado.

Feeding diabetic rats, which suffer from osteoporosis on diet containing $15 \%$ avocado and $4 \mathrm{~g}$ zinc chloride, recorded the best results in serum and liver zinc, followed by the group, which fed, on diet containing $7.5 \%$ avocado and $2 \mathrm{~g}$ zinc chloride and also the group fed on diet containing $4 \mathrm{~g}$ zinc chloride, respectively.

Low serum zinc concentrations can be the result of low zinc dietary intake; urinary zinc excretion is higher in osteoporotic women than women with no osteoporosis (Relea et al., 1995) and (Herzberg et al., 1990). On the other side, Sadighi et al., (2008) reported that, one study in Iran showed that, serum zinc decreased significantly in patients with bone fractures, as compared to the normal range; on the other hand, supplementation diet with zinc led to significant increase of this parameter and had positive effect on callus formation.

\section{Conclusion}

Fortified diet with avocado fruits and zinc chloride improved the nutritional and biochemical parameters of diabetic rats which suffering from osteoporosis. 
Egyptian J. of Nutrition Vol. XXXIV No. 1 (2019)

Table (1): Chemical composition of avocado fruits ( $g / 100 \mathrm{~g})$.

\begin{tabular}{l|l}
\hline Nutrients & Amounts (g) \\
\hline Moisture & 65.18 \\
\hline Protein & 2.05 \\
\hline Fat & 15.51 \\
\hline Ash & 1.20 \\
\hline Carbohydrate & 9.00 \\
\hline Fiber & 7.06 \\
\hline
\end{tabular}


Dalia Mohamed Talatt Abd EL-khalik

Table (2): Effect of fortified diet with avocado fruits and zinc chloride on feed intake and weight changes of rats suffering from diabetes and osteoporosis.

\begin{tabular}{|c|c|c|c|c|}
\hline Groups & $\begin{array}{c}\text { Feed intake } \\
\text { (g/day/rat) }\end{array}$ & $\begin{array}{c}\text { Initial } \\
\text { weight }(\mathrm{g})\end{array}$ & $\begin{array}{l}\text { Final weight } \\
\text { (g) }\end{array}$ & BWG\% \\
\hline \multirow{2}{*}{ Control (-ve) } & $16.910^{a}$ & $149.400^{a}$ & $195.600^{\mathrm{a}}$ & $30.902^{a}$ \\
\hline & \pm 0.618 & \pm 4.827 & \pm 7.700 & \pm 1.722 \\
\hline \multirow{2}{*}{ Control (+ve) } & $15.034^{e}$ & $150.000^{a}$ & $171.600^{b}$ & $14.408^{b}$ \\
\hline & \pm 0.212 & \pm 2.738 & \pm 2.073 & \pm 1.098 \\
\hline \multirow{2}{*}{$7.5 \%$ avocado } & $15.840^{d}$ & $150.600^{a}$ & $170.00^{b}$ & $12.893^{b c}$ \\
\hline & \pm 0.260 & \pm 1.949 & \pm 0.707 & \pm 1.161 \\
\hline \multirow{2}{*}{$15 \%$ avocado } & $15.404^{e}$ & $151.400^{a}$ & $170.800^{b}$ & $12.810^{b c}$ \\
\hline & \pm 0.289 & \pm 2.073 & \pm 3.271 & \pm 1.230 \\
\hline \multirow{2}{*}{$2 \mathrm{~g}$ zinc chloride } & $15.900^{c d}$ & $150.800^{a}$ & $171.400^{b}$ & $13.659^{b}$ \\
\hline & \pm 0.353 & \pm 2.774 & \pm 3.361 & \pm 0.707 \\
\hline \multirow{2}{*}{ 4g zinc chloride } & $15.992^{\mathrm{cd}}$ & $150.000^{a}$ & $168.800^{b}$ & $12.541^{b c}$ \\
\hline & \pm 0.195 & \pm 2.915 & \pm 2.774 & \pm 0.986 \\
\hline \multirow{2}{*}{$\begin{array}{l}7.5 \% \text { avocado } \\
\text { and } 2 \mathrm{~g} \text { zinc } \\
\text { chloride }\end{array}$} & $16.534^{b}$ & $150.000^{a}$ & $168.600^{b}$ & $9.737^{c}$ \\
\hline & \pm 0.201 & \pm 3.535 & \pm 3.714 & \pm 5.456 \\
\hline $\begin{array}{l}15 \% \text { avocado } \\
\text { and } 4 \mathrm{~g} \text { zinc } \\
\text { chloride }\end{array}$ & $\begin{array}{l}15.530^{e} \\
\pm 0.270\end{array}$ & $\begin{array}{c}149.600^{a} \\
\pm 3.209\end{array}$ & $\begin{array}{c}168.600^{b} \\
\pm 4.098\end{array}$ & $\begin{array}{c}12.699 b c \\
\pm 1.202\end{array}$ \\
\hline
\end{tabular}

BWG\%: Body weight gain\%. All results are expressed as mean \pm SD. Values in each row which have different litters are significant different $(p \leq 0.05)$. 
Egyptian J. of Nutrition Vol. XXXIV No. 1 (2019)

Table (3): Effect of fortified diet with avocado fruits and zinc chloride on lipid profile of rats suffering from diabetes and osteoporosis.

\begin{tabular}{|c|c|c|c|c|c|}
\hline \multirow{2}{*}{$\begin{array}{l}\text { Parameters } \\
\text { Groups }\end{array}$} & \multicolumn{5}{|c|}{ Lipid Profile (mg/dl) } \\
\hline & Cholesterol & Triglyceride & HDL-C & LDL-C & VLDL-C \\
\hline \multirow{2}{*}{ Control (-ve) } & $78.400^{f}$ & $37.800^{\mathrm{e}}$ & $42.600^{a}$ & $28.240^{f}$ & $7.560^{\mathrm{e}}$ \\
\hline & \pm 2.701 & \pm 2.280 & \pm 0.894 & \pm 2.535 & \pm 0.456 \\
\hline \multirow{2}{*}{ Control (+ve) } & $190.400^{\mathrm{a}}$ & $93.200^{a}$ & $17.400^{f}$ & $154.360^{\mathrm{a}}$ & $18.640^{\mathrm{a}}$ \\
\hline & \pm 3.646 & \pm 3.962 & \pm 2.073 & \pm 4.257 & \pm 0.792 \\
\hline \multirow{2}{*}{$7.5 \%$ avocado } & $178.200^{c}$ & $84.000^{b}$ & $23.400^{d}$ & $138.000^{c}$ & $16.800^{b}$ \\
\hline & \pm 1.788 & \pm 3.674 & \pm 2.180 & \pm 2.989 & \pm 0.734 \\
\hline \multirow{2}{*}{$15 \%$ avocado } & $163.200^{d}$ & $72.400^{c}$ & $30.000^{c}$ & $118.720^{d}$ & $14.480^{\circ}$ \\
\hline & \pm 3.114 & \pm 2.509 & \pm 1.581 & \pm 2.625 & \pm 0.502 \\
\hline \multirow{2}{*}{$\begin{array}{l}2 \mathrm{~g} \text { zinc } \\
\text { chloride }\end{array}$} & $184.800^{b}$ & $89.600^{a}$ & $20.400^{e}$ & $146.480^{b}$ & $17.920^{\mathrm{a}}$ \\
\hline & \pm 1.483 & \pm 4.037 & \pm 1.516 & \pm 1.404 & \pm 0.807 \\
\hline \multirow{2}{*}{$\begin{array}{l}4 \mathrm{~g} \text { zinc } \\
\text { chloride }\end{array}$} & $174.400^{c}$ & $83.400^{b}$ & $24.800^{d}$ & $133.466^{c}$ & $16.134^{b}$ \\
\hline & \pm 1.516 & \pm 4.393 & \pm 1.788 & \pm 3.328 & \pm 1.626 \\
\hline \multirow{2}{*}{$\begin{array}{l}7.5 \% \text { avocado } \\
\text { and } 2 \mathrm{~g} \text { zinc } \\
\text { chloride }\end{array}$} & $163.600^{d}$ & $72.600^{c}$ & $30.600^{c}$ & $118.480^{d}$ & $14.520^{c}$ \\
\hline & \pm 4.159 & \pm 3.646 & \pm 2.408 & \pm 4.016 & \pm 0.729 \\
\hline \multirow{2}{*}{$\begin{array}{l}15 \% \text { avocado } \\
\text { and } 4 \mathrm{~g} \text { zinc } \\
\text { chloride }\end{array}$} & $146.800^{e}$ & $60.800^{d}$ & $37.600^{b}$ & $97.040^{\mathrm{e}}$ & $12.160^{d}$ \\
\hline & \pm 5.069 & \pm 3.033 & \pm 1.816 & \pm 5.563 & \pm 0.606 \\
\hline
\end{tabular}

All results are expressed as mean \pm SD. Values in each row which have different litters are significant different $(p \leq 0.05)$. 
Dalia Mohamed Talatt Abd EL-khalik

Table (4): Effect of fortified diet with avocado and zinc chloride on bone status of rats suffering from diabetes and osteoporosis.

\begin{tabular}{|c|c|c|c|c|c|c|}
\hline \multirow{2}{*}{ Groups } & \multicolumn{6}{|c|}{ Bone status } \\
\hline & $\begin{array}{c}\text { FB (Ca) } \\
(\mathrm{mg})\end{array}$ & $\begin{array}{l}\text { FB (P) } \\
(\mathrm{mg})\end{array}$ & $\begin{array}{l}\mathrm{S}(\mathrm{Ca}) \\
\mathrm{mmol} / \mathrm{l}\end{array}$ & $\begin{array}{c}\mathrm{S}(\mathrm{P}) \\
\mathrm{mmol} / \mathrm{l}\end{array}$ & $\begin{array}{l}\text { BMD } \\
\mathrm{g} / \mathrm{cm}^{2}\end{array}$ & $\begin{array}{l}\text { BMC } \\
\mathrm{g} / \mathrm{cm}^{2}\end{array}$ \\
\hline Control (-ve) & $\begin{array}{l}96.839^{a} \\
\pm 3.048\end{array}$ & $\begin{array}{l}59.354^{\mathrm{a}} \\
\pm 2.342\end{array}$ & $\begin{array}{l}3.356^{\mathrm{a}} \\
\pm 0.065\end{array}$ & $\begin{array}{l}2.460^{a} \\
\pm 0.080\end{array}$ & $\begin{array}{l}0.178^{a} \\
\pm 0.009\end{array}$ & $\begin{array}{l}0.126^{a} \\
\pm 0.008\end{array}$ \\
\hline $\begin{array}{l}\text { Control } \\
(+\mathrm{ve})\end{array}$ & $\begin{array}{l}57.784^{f} \\
\pm 3.381\end{array}$ & $\begin{array}{l}31.691^{f} \\
\pm 1.421^{\prime}\end{array}$ & $\begin{array}{l}2.213^{f} \\
\pm 0.119\end{array}$ & $\begin{array}{r}1.540^{f} \\
\pm 0.069\end{array}$ & $\begin{array}{r}0.057^{g} \\
\pm 0.006 \\
\end{array}$ & $\begin{array}{l}0.039^{f} \\
\pm 0.004\end{array}$ \\
\hline $\begin{array}{l}7.5 \% \\
\text { avocado }\end{array}$ & $\begin{array}{c}65.324^{\mathrm{de}} \\
\pm 3.164\end{array}$ & $\begin{array}{l}39.674^{\mathrm{e}} \\
\pm 1.554\end{array}$ & $\begin{array}{l}2.519^{d} \\
\pm 0.069\end{array}$ & $\begin{array}{l}1.789^{d} \\
\pm 0.081\end{array}$ & $\begin{array}{r}0.080^{\mathrm{e}} \\
\pm 0.009\end{array}$ & $\begin{array}{l}0.064^{\mathrm{e}} \\
\pm 0.006\end{array}$ \\
\hline $\begin{array}{l}15 \% \\
\text { avocado }\end{array}$ & $\begin{array}{l}73.748^{c} \\
\pm 2.138^{2}\end{array}$ & $\begin{array}{l}46.489^{\mathrm{c}} \\
\pm 1.926\end{array}$ & $\begin{array}{l}2.801^{c} \\
\pm 0.076\end{array}$ & $\begin{array}{l}1.942^{c} \\
\pm 0.032\end{array}$ & $\begin{array}{l}0.111^{\mathrm{c}} \\
\pm 0.011\end{array}$ & $\begin{array}{l}0.090^{c} \\
\pm 0.007\end{array}$ \\
\hline $\begin{array}{l}2 \mathrm{~g} \text { zinc } \\
\text { chloride }\end{array}$ & $\begin{array}{l}62.128^{\mathrm{e}} \\
\pm 2.796\end{array}$ & $\begin{array}{l}37.676^{\mathrm{e}} \\
\pm 1.875\end{array}$ & $\begin{array}{l}2.384^{\mathrm{e}} \\
\pm 0.084^{2}\end{array}$ & $\begin{array}{l}1.652^{e} \\
\pm 0.075\end{array}$ & $\begin{array}{l}0.070^{f} \\
\pm 0.003\end{array}$ & $\begin{array}{l}0.059^{e} \\
\pm 0.003\end{array}$ \\
\hline $\begin{array}{l}\text { 4g zinc } \\
\text { chloride }\end{array}$ & $\begin{array}{l}66.738^{d} \\
\pm 2.864\end{array}$ & $\begin{array}{l}42.288^{d} \\
\pm 0.824\end{array}$ & $\begin{array}{l}2.591^{d} \\
\pm 0.077\end{array}$ & $\begin{array}{l}1.774^{d} \\
\pm 0.049\end{array}$ & $\begin{array}{l}0.095^{d} \\
\pm 0.001\end{array}$ & $\begin{array}{l}0.080^{d} \\
\pm 0.004\end{array}$ \\
\hline $\begin{array}{l}7.5 \% \\
\text { avocado } \\
\text { and } 2 \mathrm{~g} \text { zinc } \\
\text { chloride }\end{array}$ & $\begin{array}{l}70.736^{c} \\
\pm 2.745\end{array}$ & $\begin{array}{l}44.109^{d} \\
\pm 1.402\end{array}$ & $\begin{array}{l}2.756^{c} \\
\pm 0.041\end{array}$ & $\begin{array}{l}2.035^{b} \\
\pm 0.040\end{array}$ & $\begin{array}{c}0.108^{c} \\
\pm 0.007\end{array}$ & $\begin{array}{l}0.086^{c d} \\
\pm 0.007\end{array}$ \\
\hline $\begin{array}{l}15 \% \\
\text { avocado } \\
\text { and } 4 \mathrm{~g} \text { zinc } \\
\text { chloride }\end{array}$ & $\begin{array}{l}82.153^{b} \\
\pm 2.122\end{array}$ & $\begin{array}{l}56.468^{b} \\
\pm 2.306\end{array}$ & $\begin{array}{l}3.107^{b} \\
\pm 0.071\end{array}$ & $\begin{array}{l}2.118^{b} \\
\pm 0.100\end{array}$ & $\begin{array}{l}0.139^{b} \\
\pm 0.003\end{array}$ & $\begin{array}{l}0.113^{b} \\
\pm 0.005\end{array}$ \\
\hline
\end{tabular}

All results are expressed as mean \pm SD. Values in each row which have different litters are significant different $(p \leq 0.05)$. 
Egyptian J. of Nutrition Vol. XXXIV No. 1 (2019)

Table (5): Effect of fortified diet with avocado fruits and zinc chloride on serum glucose, zinc in serum and liver of rats suffering from diabetes and osteoporosis.

\begin{tabular}{|c|c|c|c|}
\hline Groups & $\begin{array}{c}\text { Serum } \\
\text { glucose } \\
(\mathrm{mg} / \mathrm{dl})\end{array}$ & $\begin{array}{l}\text { Serum zinc } \\
\mu \mathrm{g} / \mathrm{dl}\end{array}$ & $\begin{array}{l}\text { Liver zinc } \\
\mu \mathrm{g} / \mathrm{g}\end{array}$ \\
\hline Control (-ve) & $\begin{array}{l}81.400^{g} \\
\pm 3.361\end{array}$ & $\begin{array}{l}179.280^{\mathrm{a}} \\
\pm 4.432\end{array}$ & $\begin{array}{l}33.196^{a} \\
\pm 1.511\end{array}$ \\
\hline Control (+ve) & $\begin{array}{l}146.800^{a} \\
\pm 2.387\end{array}$ & $\begin{array}{l}136.720^{f} \\
\pm 2.942\end{array}$ & $\begin{array}{l}21.890^{f} \\
\pm 0.880\end{array}$ \\
\hline $7.5 \%$ avocado & $\begin{array}{l}132.800^{b} \\
\pm 2.774\end{array}$ & $\begin{array}{l}145.060^{\mathrm{e}} \\
\pm 2.768\end{array}$ & $\begin{array}{l}24.494^{\mathrm{e}} \\
\pm 0.777^{2}\end{array}$ \\
\hline $15 \%$ avocado & $\begin{array}{l}119.000^{c} \\
\pm 2.345\end{array}$ & $\begin{array}{l}153.500^{d} \\
\pm 3.376\end{array}$ & $\begin{array}{l}26.812^{d} \\
\pm 0.725\end{array}$ \\
\hline $2 \mathrm{~g}$ zinc chloride & $\begin{array}{l}129.400^{b} \\
\pm 2.880^{b}\end{array}$ & $\begin{array}{l}151.360^{d} \\
\pm 2.740\end{array}$ & $\begin{array}{l}26.822^{d} \\
\pm 0.898\end{array}$ \\
\hline $4 \mathrm{~g}$ zinc chloride & $\begin{array}{l}114.200^{d} \\
\pm 3.563\end{array}$ & $\begin{array}{l}159.640^{c} \\
\pm 2.865\end{array}$ & $\begin{array}{l}28.306^{c} \\
\pm 0.517\end{array}$ \\
\hline $\begin{array}{l}7.5 \% \text { avocado and } 2 \mathrm{~g} \text { zinc } \\
\text { chloride }\end{array}$ & $\begin{array}{l}102.600^{e} \\
\pm 2.073\end{array}$ & $\begin{array}{l}160.880^{c} \\
\pm 3.433\end{array}$ & $\begin{array}{l}28.550^{c} \\
\pm 0.916\end{array}$ \\
\hline $\begin{array}{l}15 \% \text { avocado and } 4 \mathrm{~g} \text { zinc } \\
\text { chloride }\end{array}$ & $\begin{array}{l}90.200^{f} \\
\pm 3.962\end{array}$ & $\begin{array}{l}170.240^{b} \\
\pm 3.667\end{array}$ & $\begin{array}{l}30.582^{b} \\
\pm 0.729\end{array}$ \\
\hline
\end{tabular}

All results are expressed as mean \pm SD. Values in each row which have different litters are significant different $(p \leq 0.05)$. 


\section{Dalia Mohamed Talatt Abd EL-khalik}

\section{References}

Alghamdi, S. Etab and Yousef, M.A. Fatimah (2017).

Effect of Avocado on Serum Lipids of Hyperlipidemic Rats. Current Science International, 6 (1): 199-207.

Allain, C.; Poon, L. and Chan, C. (1974).

Enzymatic determination of total serum cholesterol. Clin. Chem., 20:470-475.

Al-Timimi, D.J.: Al-Dabbagh, S.A. and Mohammed, K.A.K. (2017). Zinc status as a risk of osteoporosis. Int. J. Pharma Res. Health Sci.; 5 (2): 1686-1689.

Angus, R.M.; Sambrook, P.N.; Pocock, N.A. and Eisman, J.A. (1988).

Dietary intake and bone mineral density. Bone Miner.; 4:26577.

A.O.A.C., (2000).

Association of Official Analytical Chemist Official Methods of Analysis 17th ed., Washington, USA.

A.O.A.C. (1975).

Official methods of analysis of association of official agricultural chemists, Washington, D.C.

Baginski, E.S. (1973).

Method of calcium determination. Clin. chem. Acta., 46:49. 
Egyptian J. of Nutrition Vol. XXXIV No. 1 (2019)

Bes-Rastrollo, M.; van Dam, R. M.; Martinez-Gonzalez, M. A. Li, T. Y.; Sampson, L. L. and Hu, F. B. (2008).

Prospective study of dietary energy density and weight gain in women. Am. J. Clin. Nutr. 88(3):769-767.

Calhoun, N.R.; Smith, J.C. and Becker, K.L. (1974).

The role of zinc in bone metabolism. Clin. Orthop.; 103:21234.

Campion, J.M. and Maricic, M.J. (2003).

Osteoporosis in men. Am. Fam. Physician; 67:1521-6.

Chapman, D.G.; Castilla, R. and Campbell, J.A. (1959).

Evaluation of protein in food. Determination of protein and food efficiency ratio. Can. J. Biochem. And Physil., 37: 679686.

Chen, M.D.; Song, Y.M. and Lin, P.Y. (2000).

Zinc effects on hyperglycemia and hypoleptinemia in streptozotocin-induced diabetic mice. Horm. Metab. Res., 32 (3): 107-109.

Coetzee, M.; Haag, M.; Joubert, A.M. and Kruger, M.C. (2007).

Effects of arachidonic acid, docosahexaenoic acid and prostaglandin $E(2)$ on cell proliferation and morphology of MG-63 and MC3T3-E1 osteoblast-like cells. Prostaglandins, Leukotrienes, and Essential Fatty Acids; 76:35-45. 


\section{Dalia Mohamed Talatt Abd EL-khalik}

Daradkeh, G.; Zerie, M.; Othman, M.; Chandra, P.; Jaiosi, A.; Lubna, M.; Alowainati, B.; Mohammad, I. and Daghash, M. (2014).

Zinc Status among Type (2) Diabetes Mellitus in the State of Qatar. J. of Publ. Health Frontier, 3 (1): 4-10.

Dinubile, N. A. (2010).

A potential role for avocado-and soybean-based nutritional supplementation in the management of osteoarthritis: A review. Phys. Sportsmen., 38(2): 71-81.

Dreher, M. and Adrienne, J. (2013).

Hass Avocado Composition and Potential Health Effects. Critical Reviews in Food Science and Nutrition, 53: 738-750.

Foster, L. B. and Dumns, T. T. (1973).

Determination of triglycerides. J. Clin. Chem., 19:338-353.

FriedWald,W.T.; Leve, R.I. and Fredrickson, D.S. (1972).

Estimation of the concentration of low-density lipoprotein separation by three different methods . Cli. Chem., 18: 499502.

Fulgoni, V.L.; Dreher, M. and Davenport, A.J. (2013).

Avocado consumption is associated with better diet quality and nutrient intake, and lower metabolic syndrome risk in US adults: results from the National Health and Nutrition Examination Survey (NHANES) 2001-2008. Nutr. J., 12:1-6. 
Egyptian J. of Nutrition Vol. XXXIV No. 1 (2019)

Ghayour-Mobarhan, M.; Taylor, A.; New, S.A.; Lamb, D.J. and Ferns, G.A. (2005).

Determinants of serum copper, zinc and selenium in healthy subjects. Ann. Clin. Biochem., 42: 364-75

Guariguata, L.; Whiting, D.R. and Hambleton, I. (2014).

Global estimates of diabetes prevalence for 2013 and projections for 2035. Diabetes Res Clin Pract.; 103: 137-149.

Gudbjornsson, B.; Juliusson, U.I. and Gudjonsson, F.V. (2002).

Prevalence of long term steroid treatment and the frequency of decision making to prevent steroid induced osteoporosis in daily clinical practice. Ann Rheum Dis 61:32-36.

Gur, A.; Colpan, L. and Nas, K. (2002).

The role of trace minerals in the pathogenesis of postmenopausal osteoporosis and a new effect of calcitonin. J. Bone Miner. Metab.; 20:39-43.

Hambidge M. (2003).

Biomarkers of trace mineral intake and status. J. of Nutr., 133(Suppl. 3):948S-955S.

Hamidi ,M.S.; Corey , P.N. and Cheung, A.M. (2012).

Effects of vitamin e on bone turnover markers among us postmenopausal women. J. of Bone and Min. Res., 27 (6): 1368-1380. 


\section{Dalia Mohamed Talatt Abd EL-khalik}

Hashemipour,M.;Kelishadi,R.;Shapouri,J.;Sarrafzadegan,N.; Amini, M.; Tavakoli, N.; Movahedian-Attar, A.; Mirmoghtadaee, P. and Poursafa, P. (2009).

Effect of zinc supplementation on insulin resistance and components of the metabolic syndrome in prepubertal obese children. Hormones.;8(4):279-285.

Hegsted, D.M.; Mill, R.C.; Elvehjen, C.A. and Hart E.B. (1941). Salt mixture. J. Bio. Chem., 138-459.

Herzberg, M.; Foldes, J.; Steinberg, R. and Menczel, J. (1990).

Zinc excretion in osteoporotic women. J. of Bone and Min. Res., 5:251-257.

Hill, T.; Meunier, N.; Andriollo-Sanchez, M.; Ciarapica, D.; Hininger-Favier, I.; Polito, A.; O'Connor, J.M.; Coudray, C. and Cashman, K.D. (2005).

The relationship between the zinc nutritive status and biochemical marker of bone turnover in older European adult: the ZENITH study. European J. of Clin. Nutr., 59:S73-S78.

Hyun, T.H.; Barrett-Connor, E. and Milne, D.B. (2004).

Zinc intakes and plasma concentrations in men with osteoporosis: the Rancho Bernardo Study. Am. J. Clin. Nutr.;80:715-21.

Ibegbulem, C.O. and Chikezie, P.C. (2013).

Hypoglycemic properties of ethanolic extracts of Gongronema latifolium, Aloe perryi, Viscum album and Allium sativum administered to alloxan-induced diabetic albino rats (Rattus norvegicus). Pharmacog Commun ;3:12e16. 
Egyptian J. of Nutrition Vol. XXXIV No. 1 (2019)

Ilich, J.Z. and Kerstetter, J.E. (2000).

Nutrition in bone health revisited: a story beyond calcium. J. Am. Coll. Nutr.;19:715-37.

Jane, M. E.; Stephen, L. D.; Scott, K. P. and Daniel, A.M. (2000). Detrimental Effects of Short-term Glucocorticoid Use on the Rat Diaphragm. Phys. Thera., 80 (2): 160-167.

Jansen, J.; Karges, W. and Rink, L. (2009).

Zinc and diabetes-clinical links and molecular mechanisms. J. Nutr. Biochem.; 20:399-417.

Jayalakshmi, S. and Platel, K. (2016).

Compromised zinc status of experimental rats as a consequence of prolonged iron and calcium supplementation. Indian J. Med. Res.; 143: 238-244.

Kadhim, H.M.; Ismail, S.H.; Hussein, K.I.; Bakir, I.H.; Sahib, A.S.; Khalaf, B.H. and Hussain, S.A.R. (2006).

Effects of melatonin and zinc on lipid profile and renal function in type 2 diabetic patients poorly controlled with metformin. $J$ Pineal Res. ;41(2):189-193.

Khan, A. and Safdar, M. (2003).

Role of Diet, Nutrients, Spices and Natural Products in Diabetes Mellitus; Pak. J. of Nutr., 2 (1): 1-12.

Kahn, C.R.; Goldfine, I.D.; Neville, D.M. and DeMeyts, P. (1978). Alterations in insulin binding induced by changes in vivo in the levels of glucocorticoids and growth hormone. Endocrinology 103:1054-1066. 


\section{Dalia Mohamed Talatt Abd EL-khalik}

Kruger, M.C. and Schollum, L.M. (2005).

Is docosahexaenoic acid more effective than eicosapentaenoic acid for increasing calcium bioavailability? Prostaglandins Leukot Essent Fatty Acids; 73:327-34.

Leidi, M.; Dellera, F.; Mariotti, M. and Maier, J.A. (2011).

High magnesium inhibits human osteoblast differentiation in vitro. Magnes. Res., 24: 1-6.

Leidig-Bruckner, G. and Ziegler, R. (2001).

Diabetes mellitus - a risk for osteoporosis? Exp Clin. Endocrinol Diabetes 109 (2):S493-S514.

Liao, J.M.; Li, Q.N.; Wu, T.; Hu, B.; Huang, L.F; Li, Z.H.; Zhao, W.D.; Zhang, M.C. and Zhong, S.Z. (2003).

Effects of prednisone on bone mineral density and biomechanical characteristics of the femora and lumbar vertebras in rats. Institute of Clinical Anatomy, First Military Medical University, Guangzhou 510515, China.Di Yi Jun Yi Da XueXueBao.; 23(2):97-100.

Lopes-Virella, M.F.; Stone, S.; Ellis, S. and Collwellm, J.A. (1977). Cholesterol determination in high-density lipoproteins separated by three different methods. Clin. Chem., 23 (5): 882-893.

LopezLedesma, R.; FratiMunari, A.C.; Hernandez Dominguez, B.C.; Cervantes Montalvo, S.; Hernández Luna, M.H.; Juarez, C. and Moran Lira, S. (1996).

Monounsaturated fatty acid (avocado) rich diet for mild hypercholesterolemia. Arch. Med. Res., 27: 519-523. 
Egyptian J. of Nutrition Vol. XXXIV No. 1 (2019)

McCormack, L.A.; Laska, M.N.; Larson, N.I. and Story, M. (2010). Review of the Nutritional Implications of Farmers' Markets and Community Gardens: A Call for Evaluation and Research Efforts. J. Am. Diet. Assoc., 110:399-408.

Muynck, D. and Vanhaecke, F. (2009).

Development of a method based on inductively coupled plasma-dynamic reaction cell-mass spectrometry for the simultaneous determination of phosphorus, calcium and strontium in bone and dental tissue. Spectrochimica Acta Part B: Atomic Spectro., 64(5) : 408-415.

Nishimoto, S.K.; Chang, C.H.; Gendler, E.; Stryker, W.F. and Nimni, M.E. (1985).

The effect of aging on bone formation in rats: biochemical and histological evidence for decreased bone formation capacity. Calcified Tissue International, 37:617-624.

Oboh, G.; Isaac, A.T.; Akinyemi, A.J. and Ajani, R.A. (2014). Inhibition of Key Enzymes Linked to Type 2 Diabetes and Sodium Nitroprusside Induced Lipid Peroxidation in Rats' Pancreas by Phenolic Extracts of Avocado Pear Leaves and Fruit. International J. of Biom. Sci., 10: 208-216.

Quinkler, M.; Ekman, B.; Marelli, C.; Uddin, S.; Zelissen, P. and Murray, R.D. (2017).

Prednisolone is associated with a worse lipid profile than hydrocortisone in patients with adrenal insufficiency. Endocr Connect.; 6 (1): 1-8. 


\section{Dalia Mohamed Talatt Abd EL-khalik}

Ranasinghe, P.; Wathurapatha, W.S.; Ishara, M.H.; Jayawardana, R.; Galappatthy, P.; Katulanda, P. and Constantine, G.R. (2015).

Effects of Zinc supplementation on serum lipids: a systematic review and meta-analysis. Nutr. Metab. (Lond).; 12: 26.

Rao, U.S. and Adinew, B. (2011).

Remnant B-Cell-Stimulative and Anti-Oxidative Effects of Persea americana Fruit Extract Studied in Rats Introduced into Streptozotocin-Induced Hyperglycaemic State. African Journal of Traditional, Complementary and Alternative Medicines, 8: 210-217.

Razmandeh, R.; Nasli-Esfahani, E.; Heydarpour, R.; Faridbod, F.; Ganjali, M.R.; Norouzi, P.; Larijani1, B. and Khodaamorzideh, D. (2014).

Association of Zinc, Copper and Magnesium with bone mineral density in Iranian postmenopausal women - a case control study. J. of Diab. \& Meta. Dis., 13 (43): 1-6.

Reeves, P.G.; Nielsen, F.H. and Fahmy, G.C. (1993).

Reported of the American Institute of Nutrition adhocwriling committee on the reformulation of the AIN-76 a Rodent diet. J. Nut., 123: 1939-51.

Regu, G.M.; Kim, H.; Kim, Y.J.; Paek, J.E.; Lee, G.; Chang, N. and Kwo, O. (2017).

Association between Dietary Carotenoid Intake and Bone Mineral Density in Korean Adults Aged 30-75 Years Using Data from the Fourth and Fifth Korean National Health and Nutrition Examination Surveys (2008-2011). Nutr., 9: 1-13. 
Egyptian J. of Nutrition Vol. XXXIV No. 1 (2019)

Relea, P.; Revilla, M.; Ripoll, E.; Arribas, I.; Villa, L. F. and Rico, H. (1995).

Zinc, biochemical markers of nutrition, and type I osteoporosis. Age and Ageing, 24:303-307.

Rhen, T. and Cidlowski, J.A. (2005).

Antiinflammatory action of glucocorticoids - new mechanisms for old drugs. New England J. of Med.; 353 1711-1723.

Riboli, E. and Norat, T. (2003).

Epidemiologic evidence of the protective effect of fruit and vegetables on cancer risk. Am. J. Clin. Nutr., 78: 559S- 569S.

Rodríguez-Monforte, M.; Flores-Mateo, G. and Sánchez, E. (2015).

Dietary patterns and CVD: A systematic review and metaanalysis of observational studies. Br. J. Nutr., 114, 13411359.

Ros, E. (2003).

Dietary Cis-Monounsaturated Fatty Acids and Metabolic Control in Type 2 Diabetes. The Am. Journal of Clin. Nutr.,78: 617-625.

Sadighi, A.; Mahdavi-Roshan, M. and Sadeghzadeh, M. (2008).

The effects of zinc supplementation on serum zinc, alkaline phosphatase activity and fracture healing of bones. Saudi Med. J.; 29:1276-1279. 


\section{Dalia Mohamed Talatt Abd EL-khalik}

Schwartz, A.V. (2003).

Diabetes mellitus: Does it affect bone? Calcif Tissue Int; 73:515-519.

Schwingshack, L.; Strasser, B. and Hoffmann, G. (2011).

Effects of monounsaturated fatty acids on cardiovascular risk factors: a systematic review and meta-analysis. Ann. Nutr. Metab. 59, 76-86.

Sendecor, G. and Cochran, W. (1979).

Statistical methods $.6^{\text {th }}$, ED. lowa state collage U.S.A.:871.

Spencer, H.; Rubio, N.; Kramer, L.; Norris, C. and Osis, D. (2013). Effect of zinc supplements on the intestinal absorption of calcium. J. of the Am. Col. of Nutr., 6 (1): 47-51.

Stanely, P.; Kamalakkannan, N. and Venugopal, P. (2004).

Antidiabetic and antihyperlipidaemic effect of alcoholic Syzigium cumini seeds in alloxan induced diabetic albino rats. J. of Ethno.; 91 : 209-213.

Sultania, S.; Thakur, D. and Kulshreshtha, M. (2017).

Study of Lipid Profile in Type 2 Diabetes Mellitus Patients and its Correlation with $\mathrm{HbA} 1 \mathrm{c}$. International J. of Conte. Med. Res.; 4 (2): 437- 439.

Trinder, P. (1959).

Determination of blood glucose using 4-aminophenazone. J. Clin. Path., 22:246. 
Egyptian J. of Nutrition Vol. XXXIV No. 1 (2019)

Toma, A.; Makonnen, E. and Yimer, G. (2014).

Role of zinc in diabetes mellitus, oxidative stress and other human healthy: a review article. Am. Journal of Res. Comm., 1 (11): 411-426.

USDA (U.S. Department of Agriculture). (2011).

Avocado, almond, pistachio and walnut Composition. Nutrient Data Laboratory. USDA National Nutrient Database for Standard Reference, Release 24. U.S. Department of Agriculture. Washington, DC.

Wang, W.; Bostic, T.R. and Gu, L. (2010).

Antioxident capacities, procyanidins and pigments in avocados of different strains and cultivar. Food Chem., 122: 1193-1198.

Wang, L.; Sun, J.; Yi, Q.; Wang, X. and Ju, X. (2012).

Protective Effect of Polyphenols Extract of Adlay (Coix lachryma-jobi L. var. ma-yuen Stapf) on Hypercholesterolemia-Induced Oxidative Stress in Rats. Molecules, 17: 8886-8897.

Wien, M.; Haddad, E.; Oda, K. and Sabate, J. (2013).

A Randomized $3 \times 3$ Crossover Study to Evaluate the Effect of Hass Avocado Intake on Post-Ingestive Satiety, Glucose and Insulin Levels, and Subsequent Energy Intake in Overweight Adults. Nutr. J., 12:155.

Yamaguchi, M. (1998).

Role of zinc in bone formation and bone resorption. J. Trace Elem. Exp. Med. ;11:119-35. 


\section{Dalia Mohamed Talatt Abd EL-khalik}

Yee, H.Y. (1968).

Dietary Calcium: adequacy a vegetarian diet. Am. J. Clin. Nutr., 59 (suppl) 12385.

Zafar, M. and Naqvi, S.U.N.H. (2010).

Effects of STZ-Induced Diabetes on the Relative Weights of Kidney, Liver and Pancreas in Albino Rats: A Comparative Study. Int. J. Morphol., 28 (1):135-142.

\section{Zhang C,Lu X Tan Y, Li B Miao X, Jin L, Shi X, Zhang X,Miao Li,} $X .(2012)$.

Diabetes-induced hepatic pathogenic damage,inflammation, oxidative stress, and insulin resistance was exacerbated in zinc deficient mouse model. PloS One.;7:e49257.

Zhang, Y.H.; Cheng, Y.Y.; Hong, Y. and Wang, D.L. (2003).

Effects of zinc deficiency on bone mineralization and its mechanism in rats. Zhaong Fang Yi Xue Zhi, 37:121-124 
Egyptian J. of Nutrition Vol. XXXIV No. 1 (2019)

\section{تأثير النظام الذذائي المدعم بالأفوكادو و كلوريد الزنك على الفئران المصابة بالسكر وتعاني من هشاشة العظام}

\section{داليا محمد طلعت عبد الخالق عبد الله}

قسم الاقتصاد المنزلي , كلية التربية النوعية , جامعة الفيوم عله

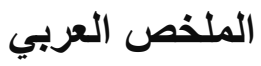

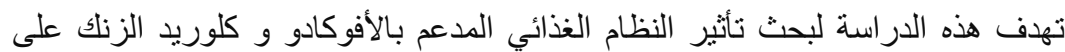

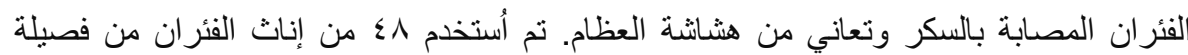

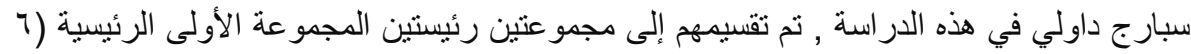
فئران) تم تغذيتها على الغذاء الأساسي وهي المجيموعة الضابطة السالبة و المجموعة الثانية

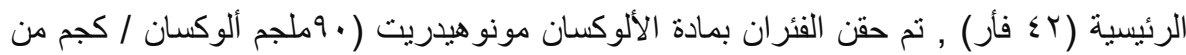
وزن الجسم ) لإحداث الإصابة بمرض السكر وبعد مرور V أيام تم تقدير مستوى الجلوكوز

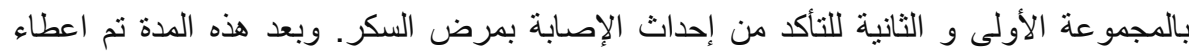

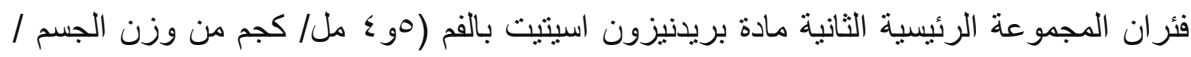

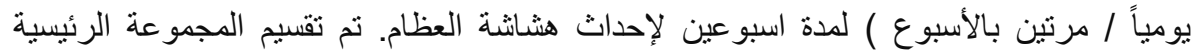

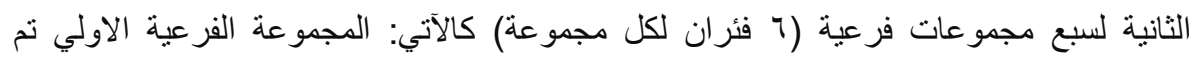

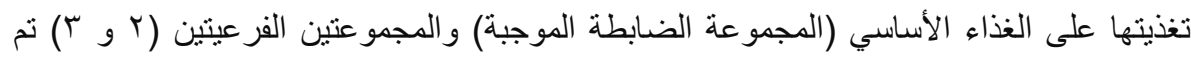

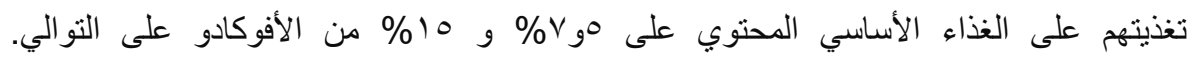

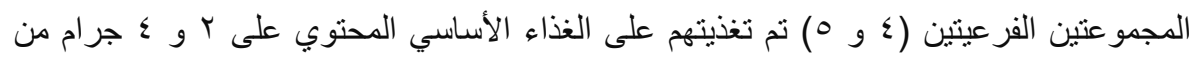

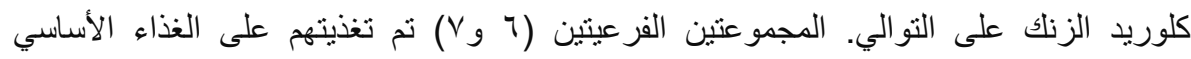

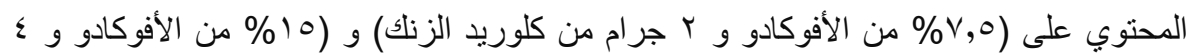

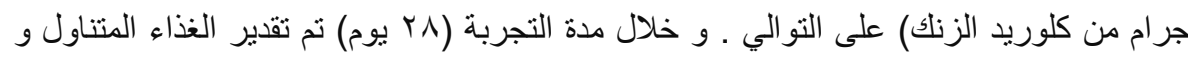

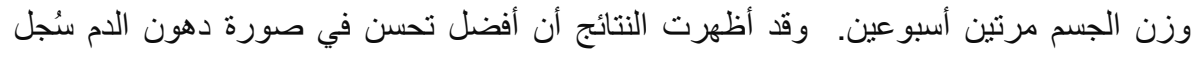

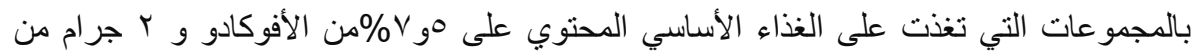

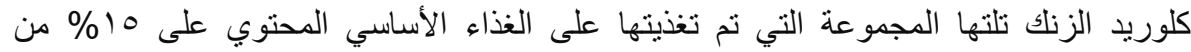
الأفوكادو و ؛ جرام من كلوريد الزنك على التوالي. المستويات المرتفعة من الأفوكادو و كلوريد

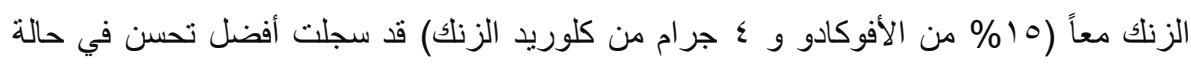

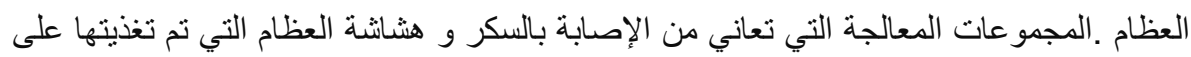




\section{Dalia Mohamed Talatt Abd EL-khalik}

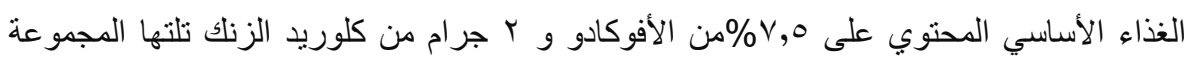

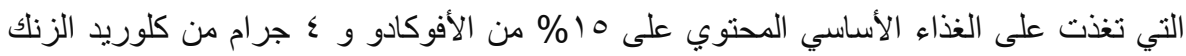

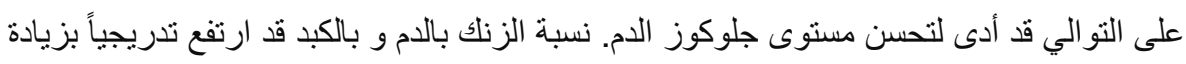
نسبة الأفوكادو و كلوريد الزنك بالنظام الغذائي ـ نستخلص من هذه النّام النتائج أن النظام الغذائي

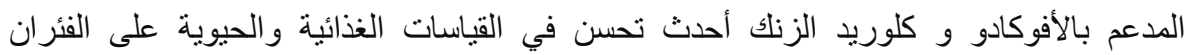
المصابة بالسكر وتعاني من هشاشتة العظام. 